\title{
Pengaruh Rekrutmen, Disiplin Kerja dan Tingkat Pendidikan Terhadap Kinerja Kepala Urusan (Kaur) di Desa (Studi pada Kepala Urusan di Desa se-Kecamatan Puring)
}

\author{
Ariawan Tri Hartono', Nur Khasanah ${ }^{2}$ \\ 1,2Sekolah Tinggi Ilmu Ekonomi Putra Bangsa \\ Email: aryngaco12@gmail.com¹, nanakhasanah.2105@gmail.com²
}

\section{ARTICLE INFO}

Article History:

Received: August $14^{\text {th }} 2020$

Accepted: October 23rd 2020

Published: December 1st 2020

Keywords:

Recruitment, Work

Discipline, Education Level,

Job Performance

\begin{abstract}
This study aims to analyze the effect of recruitment, work discipline and education level on performance on the head of affairs in villages in the District of Puring. Data collection using a questionnaire with a Likert scale and a total sample of 92 respondents. The sampling technique used in this study is saturated sampling. The hypothesis was tested using multiple regression analysis techniques, $t$ test, f test and coefficient of determination using SPSS for windows version 22.00.The results of this study indicate that recruitment partially does not significantly influence performance, work discipline partially has a positive and significant effect on performance, education level partially has a positive and significant effect on performance. Recruitment, work discipline, and education level simultaneously influence performance.
\end{abstract}

\section{Pendahuluan}

Setiap organisasi baik yang berorientasi bisnis maupun yang berorientasi sosial dituntut memberikan kinerja yang tinggi untuk pengembangan perusahaan/organisasi tersebut. Keberhasilan organisasi tersebut dipengaruhi oleh beberapa faktor, salah satu faktor penting adalah sumber daya manusia, karena sumber daya manusia merupakan pelaku dari keseluruhan tingkat perencanaan sampai dengan evaluasi yang mampu memanfaatkan sumber daya-sumber daya lainnya yang dimiliki oleh organisasi atau perusahaan. Perlu disadari bahwa pegawai merupakan sumber daya manusia yang terlibat langsung dalam menjalankan kegiatan perusahaan/organisasi. Oleh sebab itu organisasi harus memberikan perhatian secara maksimal pada pegawainya, baik perhatian dari segi kualitas pengetahuan dan keterampilan, maupun tingkat kesejahteraanya, sehingga pegawai yang bersangkutan dapat terdorong untuk memberikan segala kemampuan dan kinerja sesuai dengan yang dibutuhkan organisasi.

Salah satu organisasi yang di era teknologi ini harus meningkatkan kinerja pegawainya adalah kantor pemerintah desa, semakin berkembangnya ilmu pengetahuan dan teknologi, semakin kritis pula cara berfikir masyarakat terhadap kinerja pemerintah desa. Organisasi pemerintah 
desa merupakan tingkatan pemerintahan terendah di dalam struktur pemerintahan di Indonesia tetapi mempunyai peranan penting dan memiliki fungsi dalam pelaksanaan program-program pemerintah Keberhasilan pemerintah desa ditentukan oleh kinerja perangkat desa sebagai pembantu Kepala Desa dalam menyelenggarakan pemerintahan. Perangkat desa harus mempunyai kinerja yang baik untuk menunjang keberhasilan organisasi yaitu memberikan pelayanan kepada msayarakat dengan sebaik-baiknya.

Berdasarkan Peraturan Bupati Kebumen No. 3 Tahun 2019 yang menyatakan bahwa perangkat desa terdiri dari Sekretaris desa, Kepala Urusan, Kepala Seksi dan Kepala Dusun atau dengan sebutan lainnya. Hasil survei awal yang dilakukan oleh peneliti, diperoleh data jumlah Desa di Kecamatan Puring sebanyak 23 Desa, Sekretaris Desa 23 orang, Kepala Urusan (Kaur) 92 orang, Kepala Dusun 120 orang dan Ketua RT sebanyak 98 orang. Dalam penelitian ini fokus pada subyek Kepala Urusan sebanyak 92 orang dengan pertimbangan bahwa Kepala Urusan (Kaur) memiliki tugas pokok membantu Sekretaris Desa dalam urusan pelayanan administrasi pendukung pelaksanaan tugas-tugas pemerintahan, secara terperinci tugas masing-masing Kepala Urusan (KAUR) sebagai berikut:

1. Kepala Urusan (KAUR) Umum memiliki tugas pokok melaksanakan administrasi umum, tata usaha dan kearsipan, pengelolaan inventaris kekayaan Desa serta mempersiapkan bahan rapat dan laporan;

2. Kepala Urusan (KAUR) Keuangan memiliki tugas pokok melaksanakan pengelolaan sumber pendapatan Desa, pengelolaan administrasi keuangan Desa dan mempersiapkan bahan penyusunan APBDes;

3. Kepala Urusan (KAUR) Pemerintahan memiliki tugas pokok melaksanakan pengelolaan administrasi kependudukan, administrasi pertanahan, pembinaan, ketentraman dan ketertiban masyarakat Desa, mempersiapkan bahan perumusan kebijakan penataan, kebijakan dalam penyusunan produk hukum Desa;

4. Kepala Urusan (KAUR) Pembangunan memilki tugas pokok melaksanakan penyiapan bahan perumusan kebijakan teknis pengembangan ekonomi masyarakat dan potensi Desa, pengelolaan administrasi pembangunan, pengelolaan pelayanan masyarakat serta penyiapan bahan usulan kegiatan dan pelaksanaan tugas pembantuan.

Berdasarkan hasil penjajagan awal yang peneliti lakukan di Kecamatan Puring Kabupaten Kebumen, terdapat beberapa permasalahan yang ditemukan mengenai belum optimalnya kinerja kepala urusan (kaur), hal ini ditunjukan dari banyaknya kepala urusan (kaur) yang tidak menyerahkan laporan ke Kacamatan maupun ke Kepala desa tepat pada waktunya. Berikut data kaur keuangan yang menyerahkan laporan keuangan kepada kepala Desa:

Tabel 1. Kaur Keuangan Yang Menyerahkan Laporan Keuangan kepada Kepala Desa di Kecamatan Puring

\begin{tabular}{|c|c|c|}
\hline Tahun & $\begin{array}{l}\text { Menyerahkan } \quad \text { Laporan Keuangan } \\
\text { sebelum tanggal } 5 \text { setiap bulannya }\end{array}$ & $\begin{array}{l}\text { Menyerahkan Laporan Keuangan } \\
\text { setelah tanggal } 5 \text { setiap bulannya }\end{array}$ \\
\hline 2016 & 13 & 10 \\
\hline 2017 & 11 & 12 \\
\hline 2018 & 10 & 13 \\
\hline
\end{tabular}

Sumber: Data Primer Diolah,2020 
Dari tabel 2 menunjukkan bahwa, kinerja Kaur Keuangan selama 3 (tiga) tahun dari tahun 2016 sampai dengan tahun 2018 selalu mengalami penurunan setiap tahunnya karena masih banyak kaur keuangan yang menyerahkan laporan keuangan kepada kepala desa setelah tanggal 5 setiap bulannya.

Berikut data kaur pemerintahan yang melaporkan data kependudukan setiap bulannya ke Kepala desa sebelum selanjutnya dilaporkan ke Kecamatan Puring.

Tabel 2. Jumlah Kaur Pemerintahan yang melaporkan Data Kependudukan Ke Kepala Desa yang Selanjutnya dilaporkan ke Kecamatan Puring

\begin{tabular}{ccc}
\hline Tahun & $\begin{array}{c}\text { Melaporkan Data Kependudukan Setiap } \\
\text { Bulan }\end{array}$ & $\begin{array}{c}\text { Tidak Melaporkan Data } \\
\text { Kependudukan Setiap Bulan }\end{array}$ \\
\hline 2016 & 13 & 10 \\
2017 & 11 & 12 \\
2018 & 10 & 13 \\
\hline
\end{tabular}

Sumber: Data Primer Diolah, 2020

Dari tabel I-2 menunjukkan bahwa, kinerja kaur pemerintahan selama 3 (tiga) tahun dari tahun 2016 sampai dengan tahun 2018 selalu mengalami penurunan setiap tahunnya karena masih banyak kaur pemerintahan yang tidak melaporkan data kependudukan ke kepala desa yang selanjutnya dilaporkan ke kantor kecamatan puring.

Berdasarkan penjajagan awal yang peneliti lakukan, banyak kepala urusan umum yang tidak melaksanakan tugas pokoknya yaitu membantu sekretaris desa dalam melaksanakan administrasi umum, tata usaha dan kearsipan, pengelolaan inventaris kekayaan desa, serta mempersiapkan bahan rapat dan laporan. Fenomena yang peneliti temukan banyak kepala urusan umum yang tidak menyusun laporan pelaksanaan kegiatan sesuai bidang tugasnya untuk pertanggungjawaban pelaksanaan Anggaran Pendapatan dan Belanja Desa (APBDes). Selain itu banyak kepala urusan pembangunan yang tidak menjalankan tugas pokok dan fungsinya seperti banyak kepala urusan pembangunan yang menyusun program dan rencana kegiatan pembangunan yang akan dilaksanakan pemerintah desa secara tidak tepat waktu, disamping itu banyak kepala urusan pembangunan yang masih mengalami kesulitan dalam pengisian/ pengerjaan buku-buku administrasi desa yang menjadi tanggungjawabnya antara lain mengerjakan buku-buku: model D1, model D2, model D3, model D4, dan model lain atas kebijakan Kepala Desa yang berkaitan dengan bidang pembangunan desa.

Menurut Handoko (2010), banyak faktor yang memungkinkan mempengaruhi baik buruknya kinerja karyawan dalam melaksanakan tugas dan tanggungjawabnya. Salah satu faktor yang meyebabkan belum optimalnya kinerja kepala urusan (kaur) desa se Kecamatan Puring Kabupaten Kebumen diduga disebabkan oleh faktor pelaksanaan rekrutmen yang belum dilaksanakan dengan baik. Bila proses rekrutmen berjalan dengan baik serta berkesinambungan, maka hasilnya adalah kepala urusan (kaur) yang berkualitas akan sanggup melaksanakan pekerjaan berdasarkan peraturan perundang-undangan yang berlaku, namun yang terjadi selama ini adalah masyarakat masih mengeluh akan belum optimalnya sistem rekrutmen perangkat desa. Masyarakat menilai proses rekrutmen perangkat desa yang dilakukan disetiap desa di Kecamatan Puring belum dilaksanakan dengan baik, karena panitia penyelenggara proses rekutmen itu sendiri bukan dari pemerintah kecamatan ataupun kabupaten melainkan dari tokoh masyarakat setempat yang ditunjuk oleh kepala desa untuk membantu kepala desa dalam pelaksanaan rekrutmen perangkat desa dan masyarakat menilai tokoh masyarakat yang ditunjuk untuk membentu kepala desa dalam pelaksanaan rekrutmen belum tentu berkompeten dalam menyeleksi bakal calon perangkat desa. Sementara itu pemerintah Kabupaten hanya membentuk tim 
perekrutan perangkat desa yang dibentuk oleh BUPATI untuk memonitoring dan memfasilitasi pelaksanaan rekrutmen perangkat desa.

Faktor berikutnya yang diidentifikasikan berpengaruh pada kinerja kepala urusan (kaur) adalah disiplin kerja. Disiplin kerja menurut Sinungan (2000:146) sebagai suatu sikap mental yang tercermin dalam perbuatan atau tingkah laku perorangan, kelompok atau masyarakat berupa kepatuhan atau ketaatan (obedience) terhadap peraturan-peraturan yang ditetapkan baik oleh pemerintah atau etik, norma, dan kaidah yang berlaku dalam masyarakat untuk tujuan tertentu. Disiplin kerja memiliki peranan penting untuk meningkatkan kinerja kepala urusan (kaur), hal tersebut diperkuat oleh hasil penelitian yang dilakukan oleh Syahida dkk (2018:621) yang menyatakan bahwa disiplin kerja berpengaruh terhadap kinerja perangkat desa. Menurut Sinambela (2012:239) disiplin kerja adalah kemampuan kerja seseorang untuk secara teratur, tekun terus-menerus dan bekerja sesuai dengan aturan-aturan berlaku dengan tidak melanggar aturan-aturan yang sudah ditetapkan. Disiplin kerja juga memiliki pengaruh terhadap kinerja, dalam artian semakin tinggi disiplin kerja seseorang maka akan semakin tinggi juga kinerja seseorang tersebut (Sinambela, 2012:237).

Fenomena yang peneliti temukan di kantor-kantor pemerintah desa di kecamatan Puring adalah kepala urusan (kaur) baru akan mulai berdatangan sekitar pukul $08.30 \mathrm{WIB}$, selebihnya masih ada beberapa kepala urusan (kaur) yang kurang menaati tata tertib kantor. Terdapat beberapa kepala urusan (kaur) yang keluar kantor di waktu jam kerja untuk memenuhi kepentingan pribadinya. Rendahnya tingkat kedisiplinan kepala urusan (kaur) terlihat dari kepala urusan (kaur) yang santai pada saat jam kerja tanpa aktivitas yang berarti dan kepala urusan (kaur) yang pulangnya lebih awal (sebelum jam 16.00 WIB) padahal berdasarkan Peraturan Pemerintah (PP) Nomor 11 Tahun 2019 tentang pelaksanaan Undangundang Desa, ketentuan masuk kerja yaitu masuk kerja pukul 08.00 WIB dan pulang pukul 16.00 WIB. Berdasarkan uraian di atas dapat dikatakan bahwa disiplin kerja yang dimiliki oleh kepala urusan (kaur) di Kecamatan Puring masih terbilang rendah.

Selain rekrutmen dan disiplin kerja, tingkat pendidikan yang layak dan memadai juga akan mempengaruhi kelancaran aktivitas pekerjaan. Martoyo $(2000 ; 102)$ menyatakan faktor-faktor yang dapat mempengaruhi kinerja karyawan antara lain: motivasi, kepuasan kerja, tingkat stress, kondisi fisik, pekerjaan, pendidikan, sistem kompensasi dan aspek-aspek ekonomi. Sumber daya manusia yang berkualitas dengan pendidikan yang tinggi akan mempengaruhi kinerjanya. Berikut data tingkat pendidikan kepala urusan (KAUR) di Desa se Kecamatan Puring.

Tabel 3. Tingkat pendidikan kepala urusan (KAUR) di Desa se Kecamatan Puring

\begin{tabular}{clcc}
\hline NO & Tingkat Pendidikan & Jumlah & Presentase \\
\hline 1 & SD/Sederajat & 8 & $9 \%$ \\
2 & SLTP/Sederajat & 25 & $27 \%$ \\
3 & SLTA/Sederajat & 50 & $54 \%$ \\
4 & D3/Sarjana (S1) & 9 & $10 \%$ \\
\hline & Jumlah & 92 & $100 \%$
\end{tabular}

Sumber: Data Primer Diolah, 2020

Berdasarkan tabel 3 menunjukkan bahwa, tingkat pendidikan terakhir yang dimiliki oleh kepala urusan (KAUR) di Desa di Kecamatan puring masih beragam, hal itu diduga menjadi penyebab masih belum maksimalnya kinerja keapal urusan (KAUR) di Desa se Kecamatan Puring. Tingkat pendidikan tekahir yang dimilki oleh kepala urusan (KAUR) di Kecamatan Puring rata-rata yaitu SMA, namun masih ada beberapa kepala urusan (KAUR) yang tingkat 
pendidikan terakhirnya hanya sampai jenjang SLTP bahkan SD/Sederajat. Hal tersebut tidak sesuai dengan Peraturan Bupati Kebumen yang menyebutkan bahwa persyaratan menjadi perangkat desa di Kabupaten Kebumen berpendidikan paling rendah Sekolah Menengah Atas atau sederajat.

\section{Kajian Teori dan Telaah Literatur}

\section{Kinerja}

Menurut Mangkunegara (2002:22) Kinerja adalah hasil kerja secara kualitas dan kuantitas yang dapat dicapai seorang pegawai dalam melaksanakan tugasnya sesuai dengan tanggungjawab yang diberikan kepadanya. Menurut Robbins (2006) Indikator yang dapat digunakan untuk mengukur kinerja seorang pegawai yaitu:

a. Kualitas

Kualitas kerja diukur dari persepsi karyawan terhadap kualitas pekerjaan yang dihasilkan serta kesempurnaan tugas terhadap keterampilan dan kemampuan karyawan.

b. Kuantitas

Kuantitas merupakan jumlah yang dihasilkan dan dinyatakan dalam istilah seperti jumlah unit, jumlah siklus aktivitas yang diselesaikan.

c. Ketepatan Waktu

Ketepatan waktu merupakan tingkat aktivitas yang diselesaikan pada awal waktu yang dinyatakan, dilihat dari sudut koordinasi dengan hasil output serta memaksimalkan waktu yang tersedia untuk aktivitas lain.

\section{d. Efektivitas}

Efektivitas merupakan tingkat penggunaan sumber daya organisasi (tenaga, uang, teknologi, dan bahan baku) dimaksimalkan dengan maksud menaikan hasil dari setiap unit dalam penggunaan sumber daya.

e. Kemandirian

Kemandirian merupakan tingkat seorang karyawan yang nantinya akan dapat menjalankan fungsi kerjanya tanpa meminta bantuan, bimbingan dari orang lain atau pengawasan.

\section{Rekruitmen}

Mathis (2006) menyampaikan penarikan (rekrutmen) pegawai merupakan suatu proses atau tindakan yang dilakukan oleh organisasi untuk mendapatkan tambahan pegawai melalui beberapa tahapan mencakup identifikasi dan evaluasi sumber-sumber penarikan tenaga kerja, menentukan kebutuhan tenaga kerja, proses seleksi, penempatan, dan orientasi tenaga kerja. Indikator rekrutmen menurut Sudiro (2011:52) yaitu:

\section{a. Proses Rekrutmen}

Proses rekrutmen saat ini memiliki beberapa istilah popular yaitu job analysis (analisis jabatan), job description (uraian jabatan), job specification (persyaratan jabatan), job evaluation (penilaian jabatan), job classification (penggolongan jabatan). 


\section{b. Metode Rekrutmen}

Terdapat dua metode rekrutmen, yaitu:

1. Metode tertutup, yaitu pelaksanaan rekrutmen dikalangan terbatas, hanya untuk karyawan dan orang-orang tertentu saja, sehingga lamaran yang masuk tidak banyak dengan demikian akan sulit memperoleh karyawan yang baik.

2. Metode terbuka, yaitu pelaksanaan rekrutmen yang diumumkan melalui iklan di media massa. Hal ini dilakukan untuk mendapatkan banyak lamaran, sehingga kesempatan memperoleh karyawan yang baik dan andal menjadi lebih besar.

\section{c. Persyaratan Rekrutmen}

d. Tujuan Rekrutmen

e. Penentuan jumlah dan kualifikasi calon karyawan sesuai dengan yang dibutuhkan

f. Hasil Rekrutmen

\section{Disiplin Kerja}

Menurut Wirawan (2009:138) disiplin adalah sikap dan perilaku kepatuhan terhadap peraturan organisasi, prosedur kerja, kode etik, dan norma budaya organisasi lainnya yang harus dipatuhi dalam memproduksi suatu produk dan melayani konsumen organisasi. Alfred R.lateiner dalam soedjono (2002:72) menjelaskan bahwa, disiplin kerja memiliki beberapa indikator seperti :
a. Ketetapan waktu
Jika karyawan datang ke kantor tepat waktu, pulang kantor tepat waktu, serta karyawan dapat bersikap tertip maka dapat dikatakan karyawan tersebut memiliki disiplin kerja yang baik.

\section{b. Pemanfaatan sarana}

Karyawan yang berhati-hati dalam menggunakan peralatan kantor untuk menghindari terjadinya kerusakan pada alat kantor merupakan cerminan karyawan yang memilki disiplin kerja yang baik.

c. Tanggungjawab yang tinggi

Karyawan yang selalu menyelesaikan tugas yang dibebankan kepadanya sesuai dengan prosedur dan bertanggungjawab terhadap hasil kerjanya, dapat pula dikatakan memiliki disiplin kerja yang tinggi.

d. Ketaatan terhadap aturan kantor

Karyawan yang memakai seragam sesuai aturan, mengenakan kartu tanda identitas, ijin apbila tidak masuk kantor, juga merupakan cerminan disiplin yang tinggi.

\section{Tingkat Pendidikan}

Tingkat pendidikan diartikan sebagai pendidikan formal yang dicapai atau diperoleh dibangku sekolah. Pendidikan formal yang ditempuh merupakan modal yang amat penting karena dengan pendidikan seseorang mempunyai kemampuan dan dapat dengan mudah mengembangkan diri dalam bidang kerjanya (Handoko, 2003:126). Indikator yang dipakai untuk mengukur tingkat pendidikan menurut UU SISDIKNAS No. 20 (2003), Indikator tingkat pendidikan terdiri dari jenjang pendidikan dan kesesuaian jurusan. 


\section{a. Jenjang pendidikan}

1. Pendidikan dasar: Jenjang pendidikan awal selama 9 (sembilan) tahun pertama masa sekolah anak-anak yang melandasi jenjang pendidikan menengah.

2. Pendidikan menengah: Jenjang pendidikan lanjutan pendidikan dasar.

3. Pendidikan tinggi: Jenjang pendidikan setelah pendidikan menengah yang mencakup program sarjana, magister, doktor, dan spesialis yang diselenggarakan oleh perguruan tinggi.

b. Kesesuaian jurusan adalah sebelum karyawan direkrut terlebih dahulu perusahaan menganalisis tingkat pendidikan dan kesesuaian jurusan pendidikan karyawan tersebut agar nantinya dapat ditempatkan pada posisi jabatan yang sesuai dengan kualifikasi pendidikannya tersebut. Dengan demikian karyawan dapat memberikan kinerja yang baik bagi perusahaan.

\section{Model Penelitian}

Subjek dalam penelitian ini adalah kepala urusan di Desa se Kecamatan Puring yang berjumlah 92 orang. Instrumen yang digunakan penulis dalam pengumpulan data adalah menggunakan kuesioner yang ditujukan untuk memperoleh jawaban dari responden. Setelah data dari penyebaran kuesioner terkumpul, kemudian dilakukan proses skoring yaitu pemberian nilai atau harga yang berupa angka pada jawaban untuk memperoleh data kuantitatif yang diperlukan dalam pengujian hipotesis dengan menggunakan Skala Likert. Populasi dalam penelitian ini adalah kepala urusan di Desa se kecamatan Puring yang berjumlah 92 orang. Sampel yang diambil dari penelitian ini adalah seluruh kepala urusan (kaur) di Desa se Kecamatan Puring yang berjumlah 92 orang. Dalam perhitungan pengolahan data, peneliti menggunakan alat bantu yang berupa program aplikasi komputer yaitu SPSS (Statistical Product and Services Solutions) for windows versi 22.0. Adapun analisis yang digunakan meliputi uji validitas, uji reliabilitas, Uji Asumsi Klasik yang terdiri dari uji Multkolinearitas, uji Normalitas, uji Heteroskedastisitas. Analisis regresi berganda, uji hipotesis teridiri dari uji hipotesis parsial (uji t), uji simultan (uji F), dan koefisien determinasi (adjusted $r^{2}$ ).

\section{Hasil dan Pembahasan}

\section{Analisis deskriptif}

Berdasarkan data yang terkumpul sebanyak 92 responden diperoleh informasi mengenai karakteristik responden seperti usia responden, tingkat pendidikan terakhir dan lama kerja respondentersebut. Karakteristik responden dapat dilihat pada tabel berikut ini:

\begin{tabular}{ccc}
\multicolumn{3}{c}{ Tabel 4. } \\
\cline { 2 - 3 } Usia & Jumlah Orang & Presentase(\%) \\
\hline $20-25$ & 12 & $13 \%$ \\
$26-30$ & 15 & $16 \%$ \\
$31-35$ & 28 & $31 \%$ \\
$>36$ & 37 & $40 \%$ \\
\hline Jumlah & $\mathbf{9 2}$ & $\mathbf{1 0 0} \%$ \\
\hline
\end{tabular}

Sumber: Data primer diolah, 2020

Berdasarkan tabel tersebut, dapat diketahui bahwa paling banyak responden berumur lebih dari 36 tahun. Supriyono (2006) melakukan penelitian tentang pengaruh usia, keinginan sosial, kecukupan anggaran dan partisipasi penganggaran terhadap kinerja manajer di 
Indonesia, dengan hasil usia berpangaruh positif dan signifikan terhadap kinerja. Artinya jika usia seorang perangkat desa masih dalam kategori usia produktif, maka perangkat desa tersebut dapat memberikan kinerja yang baik bagi organisasi.

Berdasarkan data yang terkumpul dari 92 responden diperoleh data karakteristik responden berdasarkan tingkat pendidikan terakhir responden yang dapat dilihat pada tabel berikut ini:

Tabel 5. Karakteristik Responden Berdasarkan Pendidikan

\begin{tabular}{ccc}
\hline Pendidikan & Jumlah orang & Presentase(\%) \\
\hline SD/Sederajat & 6 & $7 \%$ \\
SLTP & 17 & $18 \%$ \\
SLTA & 46 & $50 \%$ \\
D3 & 11 & $12 \%$ \\
S1 & 12 & $13 \%$ \\
\hline Jumlah & $\mathbf{9 2}$ & $\mathbf{1 0 0} \%$ \\
\hline
\end{tabular}

Sumber: Data primer diolah, 2020

Berdasarkan tabel tersebut, dapat diketahui bahwa responden rata-rata memiliki pendidikan terakhir SLTA. Guspul (2016) hasil penelitiannya menyatakan salah satu faktor yang mempengaruhi kinerja yaitu tingkat pendidikan. Artinya sumber daya manusia yang berkualitas dengan pendidikan yang baik akan mempengaruhi kinerjanya. Pendidikan inilah yang membuat seorang pegawai mampu menyelesaikan tugasnya dengan baik.

Berdasarkan data yang terkumpul dari 92 responden diperoleh data karakteristik responden berdasarkan lama kerja yang dapat dilihat pada tabel berikut ini:

Tabel 6. Karakteristik Responden Berdasarkan Lama Kerja

\begin{tabular}{ccc}
\hline Lama Kerja & Jumlah Orang & Presentase(\%) \\
\hline $1-5$ & 21 & $23 \%$ \\
$6-10$ & 20 & $22 \%$ \\
$11-20$ & 23 & $25 \%$ \\
$>20$ & 28 & $30 \%$ \\
\hline Jumlah & $\mathbf{9 2}$ & $\mathbf{1 0 0} \%$ \\
\hline
\end{tabular}

Sumber: Data primer diolah 2020

Berdasarkan tabel tersebut, dapat diketahui bahwa sudah banyak perangkat desa yang menjabat lebih dari 6 tahun, maka dapat dikatakan bahwa kepala urusan di desa se Kecamatan Puring sudah bekerja cukup lama. Septarina (2017) menyatakan bahwa lama kerja mempunyai pengaruh positif dan signifikan terhadap kinerja. Artinya semakin lama masa bekerja seorang pegawai maka semakin baik pula kinerjanya, karena pada saat seorang pegawai sudah lama menekuni apa yang sudah menjadi tugasnya maka pegawai tersebut dapat menyelesaikan tugas yang diberikan dengan efektif dan efesien.

\section{Analisis Statistik}

Analisis statistik dalam penelitian ini diperoleh dari perhitungan pengolahan data sampel sebanyak 92 responden dengan menggunakan alat bantu berupa program aplikasi komputer SPSS (Statistical Product and Service Solutions) for windows versi 22.0. 


\section{Uji Validitas}

Uji validitas digunakan untuk mengukur valid atau tidaknya suatu kuisioner yang dilakukan terhadap semua instrument variabel, baik variabel bebas, terikat, maupun intervening. Butir pernyataan dapat dikatakan valid apabila $r_{\text {hitung }}>r_{\text {tabel }}$ dengan taraf signifikan $5 \%$, sedangkan untuk menentukan $\mathrm{r}_{\text {tabel }}$ yaitu dengan rumus $\mathrm{df}=\mathrm{N}-2$

Dimana $: \mathrm{Df}=$ degree of fredoom $; \mathrm{N}=$ sampel $\mathrm{df}=92-2=90$, diperoleh $\mathrm{r}$ tabel $=0,2050$

Hasil uji validitas variabel rekrutmen (X1) disajikan dalam bentuk tabel sebagai berikut:

Tabel 7. Hasil Uji Validitas Variabel Rekrutmen

\begin{tabular}{ccccc}
\hline Butir & $\mathbf{r}_{\text {hitung }}$ & $\mathbf{r}_{\text {tabel }}$ & Signifikansi & Keterangan \\
\hline X1.1 & 0,334 & 0,2050 & 0,001 & Valid \\
X1.2 & 0,405 & 0,2050 & 0,000 & Valid \\
X1.3 & 0,628 & 0,2050 & 0,000 & Valid \\
X1.4 & 0,694 & 0,2050 & 0,000 & Valid \\
X1.5 & 0,692 & 0,2050 & 0,000 & Valid \\
X1.6 & 0,478 & 0,2050 & 0,000 & Valid \\
X1.7 & 0,746 & 0,2050 & 0,000 & Valid \\
\hline
\end{tabular}

Sumber: Data Primer Diolah, 2020

Berdasarkan tabel 7 di atas, menunjukkan bahwa seluruh item/butir pernyataan yang digunakan untuk mengukur variabel rekrutmen dinyatakan valid (sah), karena diperoleh nilai

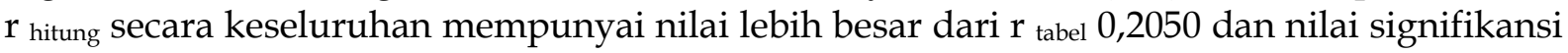
lebih kecil dari 0,05 . Hasil uji validitas disiplin kerja $\left(\mathrm{X}_{2}\right)$ disajikan dalam bentuk tabel sebagai berikut:

Tabel 8. Hasil Uji Validitas Variabel Disiplin Kerja

\begin{tabular}{ccccc}
\hline Butir & $\mathbf{r}_{\text {hitung }}$ & $\mathbf{r}_{\text {tabel }}$ & Signifikansi & Keterangan \\
\hline X2.1 & 0,606 & 0,2050 & 0,000 & Valid \\
X2.2 & 0,470 & 0,2050 & 0,000 & Valid \\
X2.3 & 0,624 & 0,2050 & 0,000 & Valid \\
X2.4 & 0,551 & 0,2050 & 0,000 & Valid \\
X2.5 & 0,581 & 0,2050 & 0,000 & Valid \\
X2.6 & 0,526 & 0,2050 & 0,000 & Valid \\
X2.7 & 0,545 & 0,2050 & 0,000 & Valid \\
\hline
\end{tabular}

Sumber: Data Primer Diolah, 2020

Berdasarkan tabel 8 di atas, menunjukkan bahwa seluruh item/butir pernyataan yang digunakan untuk mengukur variabel disiplin kerja dinyatakan valid (sah), karena diperoleh nilai $r$ hitung secara keseluruhan mempunyai nilai lebih besar dari $r$ tabel 0,2050 dan nilai signifikansi lebih kecil dari 0,05. Hasil uji validitas disiplin kerja $\left(\mathrm{X}_{3}\right)$ disajikan dalam bentuk tabel sebagai berikut:

Tabel 9. Hasil Uji Validitas Variabel Tingkat Pendidikan

\begin{tabular}{ccccc}
\hline Butir & $\mathbf{r}_{\text {hitung }}$ & $\mathbf{r}_{\text {tabel }}$ & Signifikansi & Keterangan \\
\hline X3.1 & 0,603 & 0,2050 & 0,000 & Valid \\
X3.2 & 0,936 & 0,2050 & 0,000 & Valid \\
X3.3 & 0,893 & 0,2050 & 0,000 & Valid \\
X3.4 & 0,947 & 0,2050 & 0,000 & Valid \\
\hline
\end{tabular}

Sumber: Data Primer Diolah, 2020 
Berdasarkan tabel 9 di atas, menunjukkan bahwa seluruh item/butir pernyataan yang digunakan untuk mengukur variabel tingkat pendidikan dinyatakan valid (sah), karena diperoleh nilai $r$ hitung secara keseluruhan mempunyai nilai lebih besar dari $r$ tabel 0,2050 dan nilai signifikansi lebih kecil dari 0,05 . Hasil uji validitas Kinerja $(Y)$ disajikan dalam bentuk tabel sebagai berikut:

Tabel 10. Hasil Uji Validitas Variabel Kinerja

\begin{tabular}{ccccc}
\hline Butir & $\mathbf{r}_{\text {hitung }}$ & $\mathbf{r}_{\text {tabel }}$ & Signifikansi & Keterangan \\
\hline Y.1 & 0,600 & 0,2050 & 0,000 & Valid \\
Y.2 & 0,739 & 0,2050 & 0,000 & Valid \\
Y.3 & 0,773 & 0,2050 & 0,000 & Valid \\
Y.4 & 0,708 & 0,2050 & 0,000 & Valid \\
Y.5 & 0,536 & 0,2050 & 0,000 & Valid \\
\hline
\end{tabular}

Sumber: Data Primer Diolah, 2020

Berdasarkan tabel 10 di atas, menunjukkan bahwa seluruh item/butir pernyataan yang digunakan untuk mengukur variabel kinerja dinyatakan valid (sah), karena diperoleh nilai $r$ hitung secara keseluruhan mempunyai nilai lebih besar dari $r_{\text {tabel }}$ 0,2050 dan nilai signifikansi lebih kecil dari 0,05.

\section{Uji Reabilitas}

Reliabilitas yang tinggi menunjukan bahwa indikator memiliki konsistensi yang tinggi dalam mengukur variabel laten. Pengujiannya menurut Ghozali (2009), adalah jika cronbach alpha lebih besar dari 0,60 maka butir atau variabel tersebut dinyatakan reliabel dan sebaliknya jika cronbach alpha kurang dari 0,60, maka butir atau variabel tersebut dinyatakan tidak reliabel. Hasil uji reabilitas penelitian ini disajikan dalam bentuk tabel sebagai berikut:

Tabel 11. Hasil Uji Reliabilitas

\begin{tabular}{cccc}
\hline No & Item Variabel & Cronbach Alpha & Keterangan \\
\hline 1 & Rekrutmen & 0,634 & Reliabel \\
2 & Disiplin Kerja & 0,644 & Reliabel \\
3 & Tingkat Pendidikan & 0,877 & Reliabel \\
4 & Kinerja & 0,684 & Reliabel \\
\hline
\end{tabular}

Sumber: Data Primer Diolah, 2020

Berdasarkan Tabel IV-8 di atas, dapat dijelaskan bahwa seluruh variabel yang digunakan dalam penelitian ini dinyatakan reliabel (andal) karena nilai cronbach alpha lebih besar dari 0,60 . 


\section{Uji Asumsi Klasik}

\section{Uji Multikolinearitas}

Tidak adanya multikolinearitas ditentukan dengan angka VIF dibawah 10 dan tolerance diatas 0,1 (Ghozali, 2006:96). Hasil analisis data dengan bantuan program SPSS for Windows Version 22.0 diperoleh output sebagai berikut:

Tabel 12. Hasil Uji Multikolinearitas

\begin{tabular}{clcc}
\hline No & \multicolumn{1}{c}{ Variabel } & Tolerance & VIF \\
\hline 1 & Rekrutmen & 0,974 & 1,027 \\
2 & Disiplin Kerja & 0,769 & 1,300 \\
3 & Tingkat Pendidikan & 0,766 & 1,305 \\
\hline
\end{tabular}

Sumber: Data Primer Diolah, 2020

Berdasarkan tabel 12 di atas, dapat dijelaskan bahwa nilai tolerance diatas 0,10 dan VIF dibawah angka 10, sehingga model regresi tidak terjadi multikolinearitas.

\section{Uji Heteroskedastisitas}

Uji heteroskedastisitas ini dilakukan untuk menguji apakah dalam sebuah model regresi terdapat ketidaksamaan varian dari suatu pengamatan ke pengamatan lainnya. Adapaun hasil analisisnya dapat dilihat pada gambar berikut ini:

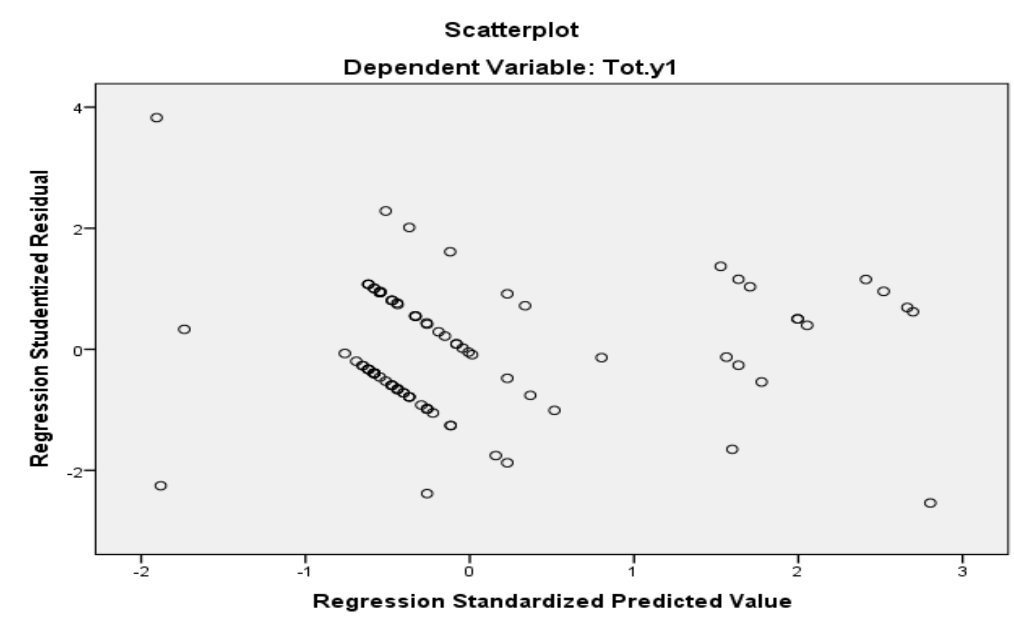

Gambar 1. Uji Heteroskedastisitas

Sumber: Data primer Diolah, 2020

Berdasarkan Gambar di atas, menunjukkan bahwa tidak ada pola tertentu seperti titik-titik yang membentuk suatu pola tertentu yang teratur (melebar, menyempit) dan tidak ada pola yang jelas sehingga dapat disimpulkan model regresu pada penelitian ini tidak terjadi heteroskedastisitas. 


\section{Uji Normalitas}

Uji normalitas ini dilakukan untuk mengetahui apakah dalam sebuah regresi linear, variabel dependen, variabel independen atau keduanya terdistribusi normal atau mendekati normal. Model regresi yang baik seharusnya mempunyai distribusi data normal atau mendekati normal. Adapun hasil analisinya dapat dilihat pada gambar berikut ini:

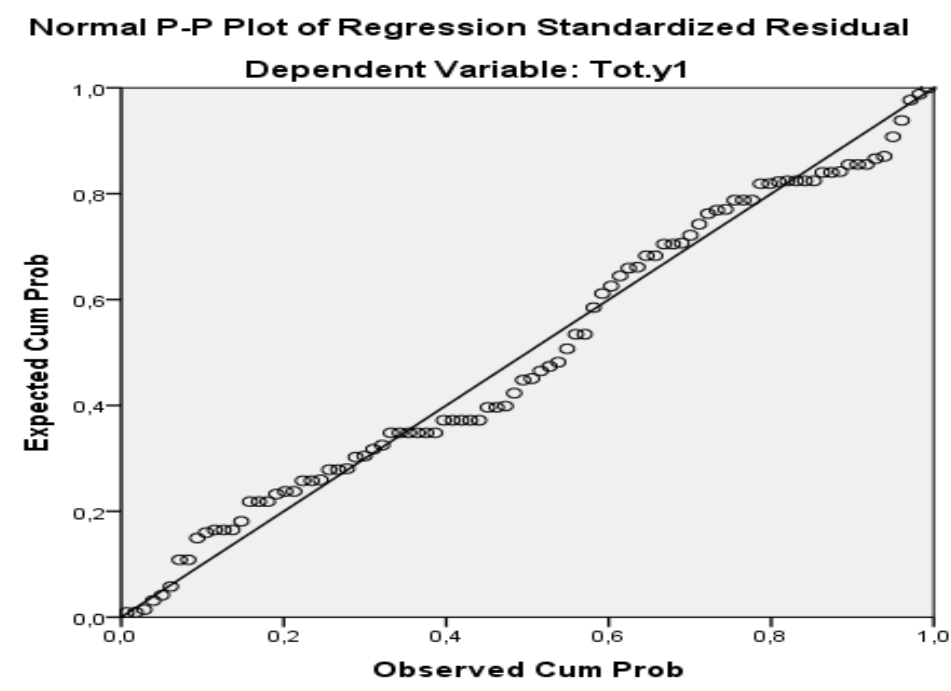

\section{Gambar 2. Uji Normalitas}

Sumber: Data Primer Diolah, 2020

Berdasarkan Gambar IV-3 di atas, diketahui bahwa data menyebar disekitas garis diagonal dan mengikuti arah garis diagonal, maka dapat disimpulkan model regresi tersebut memenuhi asumsi normalitas.

\section{Analisis Regresi Berganda}

Analisis ini digunakan untuk mengetahui sejauh mana pengaruh dari variabel rekrutmen, disiplin kerja dan tingkat pendidikan terhadap kinerja. Adapun hasil dari perhitungan dengan menggunakan bantuan SPSS for Windows Version 22.0 dapat dilihat pada tabel berikut ini:

Tabel 13. Hasil Analisis Regresi Linier Berganda

\begin{tabular}{|c|c|c|c|c|c|}
\hline \multirow[b]{2}{*}{ Model } & \multicolumn{2}{|c|}{$\begin{array}{l}\text { Unstandardized } \\
\text { Coefficients }\end{array}$} & $\begin{array}{l}\text { Standardized } \\
\text { Coefficients }\end{array}$ & \multirow[b]{2}{*}{$\mathrm{T}$} & \multirow[b]{2}{*}{ Sig. } \\
\hline & $\mathrm{B}$ & Std. Error & Beta & & \\
\hline (Constant) & ,960 & 1,324 & & ,725 & , 470 \\
\hline Rekrutmen & ,046 &, 044 & 054 & 1,053 & ,295 \\
\hline Disiplin Kerja & 188 & ,058 & 186 & 3,217 & ,002 \\
\hline Tingkat Pendidikan & 827 & ,063 & ,765 & 13,176 & 000 \\
\hline
\end{tabular}

a. Dependent Variable: Kinerja

Berdasarkan persamaan di atas, maka hasilnya adalah sebagai berikut:

$\mathrm{Y}=0,960+0,046 \mathrm{X}_{1}+0,188 \mathrm{X}_{2}+0,827 \mathrm{X}_{3}+\mathrm{e}$

1. Konstanta $(\mathrm{a})=0,960$

Nilai konstanta sebesar 0,960 menunjukan bahwa jika variabel rekrutmen $\left(X_{1}\right)$, disiplin kerja $\left(X_{2}\right)$, dan tingkat pendidikan $\left(X_{3}\right)$ sama dengan nol, maka nilai kinerja sebesar 0,960. 
2. $X_{1}=0,046$

Nilai koefisien regresi rekrutmen $\left(X_{1}\right)$ sebesar 0,046 . Jika diasumsikan variabel independen lain konstan, hal ini berarti bahwa setiap kenaikan rekrutmen $\left(X_{1}\right)$ sebesar satu satuan maka akan menaikkan kinerja sebesar 0,046.

3. $\mathrm{X}_{2}=0,188$

Nilai koefisien regresi disiplin kerja $\left(\mathrm{X}_{2}\right)$ sebesar 0,188 artinya jika disiplin kerja mengalami kenaikan sebesar satu satuan, maka kinerja akan mengalami peningkatan sebesar 0,188 jika variabel lain dianggap tetap.

4. $\mathrm{X}_{3}=0,827$

Nilai koefisien regresi variabel tingkat pendidikan $\left(\mathrm{X}_{3}\right)$ sebesar 0,827 . Jika diasumsikan variabel independen lain konstan, hal ini berarti bahwa setiap kenaikan tingkat pendidikan $\left(X_{3}\right)$ sebesar satu satuan maka akan menurunkan kinerja sebesar 0,827.

\section{Uji Hipotesis}

\section{Uji Parsial (Uji t)}

Pengujian ini merupakan suatu pengujian secara parsial variabel independen $(\mathrm{X})$ dimana untuk mengetahui pengaruh yang signifikan terhadap variabel dependen $(\mathrm{Y})$, yaitu variabel rekrutmen $\left(\mathrm{X}_{1}\right)$, disiplin kerja $\left(\mathrm{X}_{2}\right)$, dan tingkat pendidikan $\left(\mathrm{X}_{3}\right)$ terhadap kinerja $(\mathrm{Y})$. Dalam pengujian ini ditentukan tingkat signifikan sebesar $5 \%(\alpha=0,05)$. Untuk mengetahui hasil analisis uji $\mathrm{t}$ dalam penelitian ini dapat dilihat pada tabel berikut ini:

Tabel 14. Hasil Uji Parsial (Uji t)

\begin{tabular}{lccccl}
\hline Variabel & Signifikan & $\alpha$ & $\mathrm{t}_{\text {hitung }}$ & $\mathrm{t}_{\text {tabel }}$ & Keterangan \\
\hline Rekrutmen & 0,295 & 0,05 & 1,053 & 1,986 & $\begin{array}{l}\text { Tidak } \\
\text { Signifikan }\end{array}$ \\
$\begin{array}{l}\text { Disiplin } \\
\text { Kerja }\end{array}$ & 0,002 & 0,05 & 3,217 & 1,986 & Signifikan \\
$\begin{array}{l}\text { Tingkat } \\
\text { Pendidikan }\end{array}$ & 0,000 & 0,05 & 13,176 & 1,986 & Signifikan \\
\hline
\end{tabular}

Sumber : Data Primer Diolah, 2020

\section{a. Variabel rekrutmen $\left(X_{1}\right)$}

Berdasarkan Tabel IV-11 di atas, diketahui bahwa hasil analisis variabel rekrutmen memiliki $t$ hitung sebesar 1,053 $<\mathrm{t}$ tabel sebesar 1,986 dengan tingkat signifikan 0,259 > 0,05. Hal ini menunjukan bahwa variabel rekrutmen tidak berpengaruh positif dan tidak signifikan terhadap kinerja kepala urusan (KAUR) di desa se kecamatan Puring.

b. Variabel Disiplin Kerja $\left(X_{2}\right)$

Berdasarkan Tabel IV-11 di atas, diketahui bahwa hasil analisis variabel Disiplin Kerja memiliki $t$ hitung sebesar 3,217 $>t$ tabel sebesar 1,986 dengan tingkat signifikan 0,002 <0,05. Hal ini menunjukan bahwa variabel disiplin Kerja berpengaruh positif dan signifikan terhadap kinerja kepala urusan (KAUR) di desa se Kecamatan Puring.

c. Variabel Tingkat Pendidikan $\left(X_{3}\right)$

Berdasarkan Tabel IV-11 di atas, diketahui bahwa hasil analisis variabel tingkat Pendidikan memiliki $t_{\text {hitung }}$ sebesar 13,176 $>t_{\text {tabel }}$ sebesar 1,986 dengan tingkat signifikansi 0,000<0,05. Hal ini menunjukan bahwa variabel Tingkat Pendidikan berpengaruh positif dan signifikan terhadap kinerja kepala urursan (KAUR) di desa se Kecamatan Puring.

\section{Uji Simultan (Uji F)}

Uji F digunakan untuk mengetahui apakah terdapat hubungan yang nyata antara variabel rekrutmen, disiplin kerja, dan tingkat pendidikan terhadap variabel dependen yaitu kinerja 
secara bersama-sama. Hasil uji F yang telah dilakukan dengan menggunakan bantuan SPSS for windows version 22.0 dapat dilihat sebagai berikut:

Tabel 15.Hasil Uji Simultan (Uji F)

ANOVA $^{\mathrm{a}}$

\begin{tabular}{|c|c|c|c|c|c|c|}
\hline Model & & $\begin{array}{l}\text { Sum of } \\
\text { Squares }\end{array}$ & Df & $\begin{array}{l}\text { Mean } \\
\text { Square }\end{array}$ & $\mathrm{F}$ & Sig. \\
\hline \multirow[t]{3}{*}{1} & Regression & 155,984 & 3 & 51,995 & 99,810 &, $000^{\mathrm{b}}$ \\
\hline & Residual & 45,842 & 88 & ,521 & & \\
\hline & Total & 201,826 & 91 & & & \\
\hline
\end{tabular}

a. Dependent Variable: Tot.y1

b. Predictors: (Constant), Tot.x3, Tot.x1, Tot.x2

Sumber: Data Diolah Primer, 2020

Berdasarkan tabel 15 di atas, diketahui bahwa nilai $\mathrm{F}_{\text {hitung }}$ sebesar 99,810 lebih besar dari $\mathrm{F}_{\text {tabel }}$ sebesar 2,71 dengan signifikansi 0,000 dan lebih kecil dari $a=0,05$, maka dapat disimpulkan bahwa secara bersama-sama rekrutmen, disiplin kerja, dan tingkat pendidikan terhadap kinerja kepala urusan (KAUR) di desa se Kecamatan Puring.

\section{Koefisien Determinasi $\left(\mathbf{R}^{2}\right)$}

Koefisien determinasi $\left(\mathrm{R}^{2}\right)$ pada intinya mengukur seberapa jauh kemampuan model dalam menerangkan variabel dependen. Kemampuan variabel independen dalam menjelaskan variabel dependen dapat diketahui dari besarnya nilai Adjusted $\mathrm{R}^{2}$. Berikut ini hasil uji koefisien determinasi $\left(\mathrm{R}^{2}\right)$ yang diolah dengan alat bantu analisis SPSS for windows version 22.0.

Tabel 16. Hasil Uji Koefisien Determinasi $\left(\mathbf{R}^{2}\right)$

Model Summary

\begin{tabular}{lrrrr}
\hline Model & R & R Square & Adjusted R Square & $\begin{array}{c}\text { Std. Error of the } \\
\text { Estimate }\end{array}$ \\
\hline 1 &, $879^{a}$ &, 773 &, 765 &, 722
\end{tabular}

a. Predictors: (Constant), rekrutmen, disiplin kerja, tingkat pendidikan

b. Dependent Variable: Kinerja

Sumber: Data Diolah Primer, 2020

Berdasarkan tabel 16 di atas, dapat diketahui bahwa nilai Adjusted R Square sebesar 0,765 artinya kontribusi variabel rekrutmen, disiplin kerja, tingkat pendidikan terhadap kinerja kepala urusan (KAUR) di desa se kecamatan puring sebesar 76,5\% sedangkan sisanya sebesar $23,5 \%$ dipengaruhi oleh variabel lain yang tidak ada dalam model penelitian ini.

\section{Penutup dan Saran}

\section{Kesimpulan}

Berdasarkan hasil penelitian yang telah dianalisis dengan bantuan alat analisis SPSS 22.0 for windows mengenai pengaruh rekrutmen, disiplin kerja dan tingkat pendidikan terhadap kinerja (Studi pada kepala urusan di Desa se Kecamatan Puring), maka peneliti dapat menarik simpulan sebagai berikut: 
Rekruitmen tidak berpengaruh terhadap kinerja kepala urusan (KAUR) di Desa se-Kecamatan Puring. Hal ini dapat dilihat dari nilai $t$ hitung < $t$ tabel, sehingga hipotesis pertama yang menyatakan bahwa rekrutmen berpengaruh secara parsial terhadap kinerja kepala urusan (kaur) di Desa se Kecamatan Puring ditolak.

Disiplin kerja berpengaruh positif terhadap kinerja kepala urusan (KAUR) di Desa se Kecamatan Puring. Hal ini dapat dilihat dari nilai $t$ hitung $>t$ tabel, sehingga hipotesis kedua yang menyatakan bahwa disiplin kerja berpengaruh secara parsial terhadap kinerja kepala urusan (kaur) di Desa se-Kecamatan Puring diterima.

Tingkat pendidikan berpengaruh positif terhadap kinerja kepala urusan (KAUR) di Desa seKecamatan Puring. Hal ini dapat dilihat dari nilai t hitung $>t$ tabel, sehingga hipotesis ketiga yang menyatakan bahwa tingkat pendidikan berpengaruh secara parsial terhadap kinerja kepala urusan (kaur) di Desa se Kecamatan Puring diterima.

\section{Saran}

\section{Saran Untuk Kantor-Kantor Pemerintah Desa se Kecamatan Puring:}

1. Berdasarkan hasil penilitian ini rekrutmen tidak berpengaruh signifikan terhadap kinerja kepala urusan (kaur) di Desa se Kecamatan Puring. Hasil penelitian menunjukkan rekrutmen tidak berpengaruh terhadap kinerja karena nilai $\mathrm{t}$ hitung $<\mathrm{t}$ tabel, akan tetapi hasilnya masih positif yang berarti proses rektumen mungkin berpengaruh secara tidak langsung terhadap kinerja kepala urusan (kaur) di Desa se Kecamatan Puring, seharusnya variabel rekrutmen dimediasi oleh variabel lain agar berpengaruh terhadap kinerja kepala urusan (kaur). Pemerintah diharapkan selalu memperhatikan hal-hal yang biasanya ada saat proses rekrtumen seperti panitia rekrutmen, metode rekrutmen, sumber rekrutmen serta hambatan-hambatan yang biasanya muncul saat proses rekrutmen agar proses rekrutmen dapat berjalan dengan baik.

2. Berdasarkan hasil penelitian ini disiplin kerja berpengaruh positif dan signifikan terhadap kinerja. Artinya semakin tinggi disiplin kerja kepala urusan (kaur) maka semakin tinggi pula kinerja yang dihasilkan oleh kepala urusan (kaur), karena saat kepala urusan (kaur) memiliki disiplin kerja yang tinggi maka kepala urusan (kaur) akan dapat menyelesaikan tugas-tugasnya dengan tepat waktu.

3. Berdasarkan hasil penelitian ini tingkat pendidikan berpengaruh positif dan signifikan terhadap kinerja kepala urusan (kaur) di Desa. Artinya semakin tinggi tingkat pendidikan yang dimiliki oleh kepala urusan maka semakin tinggi pula kinerja yang dihasilkan, jika kepala urusan (kaur) memiliki tingkat pendidikan yang tinggi akan dapat menyelesaikan tugas-tugasnya dengan efektif dan efisien karena kepala urusan (kaur) tersebut memiliki wawasan atau pengetahuan yang berguna dalam penyelesaian tugas-tugasnya.

\section{Saran untuk Peneliti Selanjutnya}

1. Penelitian selanjutnya diharapkan untuk mengembangkan hasil penelitian ini dengan memperluas variabel-variabel bebas yang diperkirakan dapat mempengaruhi kinerja kepala urusan (kaur) selain faktor rekrutmen, disiplin kerja dan tingkat pendidikan, misalnya faktor motivasi, kepuasan kerja, kompensasi.

2. Penelitian selanjutnya diharapkan dapat mengembangkan hipotesis dari penelitian ini. Penelitian ini masih menggunakan hipotesis yang sederhana, maka dari itu sebaiknya penelitian selanjutnya dapat dimoderasi agar hipotesisnya bervariasi. 


\section{Referensi}

Arikunto, S. (2014). Prosedur Penelitian Suatu Pendekatan Praktik. Jakarta: PT Rineka Cipta.

Arisom, G. J. (2017). Pengaruh rekrutmen dan Pelatihan terhadap Kinerja Guru SD, SMP, SMA Saint John Harapan Indah Di Kota Bekasi. NCBM 2017 Kalbis Institute. ISBN 978602-50503-0-5, 1-10.

Ghozali, I. (2009). Aplikasi Analisis Multivariate dengan Program SPSS, Edisi Keempat. Semarang: Penerbit Universitas Diponegoro.

Guspul, A., \& Solehatun, S. (2017). Tingkat Pendidikan, Masa Kerja, Motivasi Kerja Pengaruhnya Terhadap Kinerja Perangkat Desa di Kecamatan Kaliwiro Wonosobo. Jurnal Penelitian dan Pengabdian Kepada Masyarakat UNSIQ, 4(1), 74-89.

Handoko, T. H. (2010). Manajemen Personalia dan Sumber Daya Manusia. Yogyakarta: BPFE.

Hasbullah. (2009). Dasar-Dasar Ilmu Pendidikan. Jakarta: Raja Grafindo Persada

Hasibuan, M. (2001). Manajemen Sumber Daya Manusia: Pengertian Dasar, dan Masalah. Jakarta: Toko Gunung Agung.

Mamahit, R. (2013). Tingkat Pendidikan, Pelatihan dan Kepuasan Kerja Pengaruhnya Terhadap Kinerja Pegawai di Badan Penanggulangan Bencana Provinsi Sulawesi Utara. Jurnal EMBA: Jurnal Riset Ekonomi, Manajemen, Bisnis dan Akuntansi, 1(4), 936945.

Mangkunegara, A. P. (2005). Perilaku dan Budaya Organisasi. Bandung: Refika Aditama.

Martoyo, S. (2000). Manajemen Sumber Daya Manusia. Yogyakarta: BPFE-Yogyakarta.

Mukayan, I., \& Ruzikna, R. (2017). Pengaruh Rekrutmen Terhadap Kinerja Karyawan (Kasus Hotel Resty Menara Pekanbaru) Periode 2014 - 2016. JOM FISIP, 4(2), 1-14.

Nitisemito, A. S. (2002). Manajemen Personalia. Edisi Revisi. Jakarta: Ghalia Indonesia.

Notoatmodjo, S. (2010). Pengembangan Sumber Daya Manusia. Jakarta: Penerbitan Rineka Cipta.

Nurmansyah, S. R. (2011). Manajemen Sumber Daya Manusia Suatu Pengantar. Pekanbaru: Unilak Press

Priyanto. D. (2016). Belajar Alat Analisis Data dan Cara Pengelolaannya dengan Cara SPSS. Yogyakarta: Gava Media.

Rifai, V., Basri, A. F. W. M., Sagala, E. J., \& Murni, S. (2005). Performance Appraisal, Sistem Yang Tepat untuk Menilai Kinerja Karyawan dan Meningkatkan daya saing Perusahaan. Jakarta: PT RajaGrafindo Persada.

Robbins, P. S. (2006). Perilaku Organisasi. Edisi Sepuluh. Diterjemahkan Oleh: Drs. Benyamin Molan. Jakarta: Erlangga.

Santoso, E. (2018). Analisis Pengaruh Disiplin Kerja, Kompensasi dan Kompetensi Terhadap Kinerja Perangkat Desa di Kecamatan Adimulyo Kabupaten Kebumen. Skripsi Sarjana. (Tidak Dipublikasikan). Sekolah Tinggi Ilmu Ekonomi Putra Bangsa.

Santoso, S. (2010). Statistik Parametik, Konsep dan Aplikasi dengan SPSS. Jakarta: Gramedia.

Simamora, H. (2006). Manajemen Sumber Daya Manusia. Yogyakarta: STIE YKPN. 
Sinambela, L. (2012). Kinerja Pegawai. Yogyakarta: Graha Ilmu

Sinungan, A. (2000). Manajemen Sumber Daya Manusia. Jakarta: Bumi Aksara

Siswanto, S. (2003). Manajemen Tenaga Kerja Indonesia. Edisi Ke 2. Jakarta: PT Bumi Aksara.

Soedjono. (2002). Pengaruh Budaya Organisasi Terhadap Kinerja Organisasi. Yogyakarta: STIM YKPN.

Sudiro. (2011). Perencanaan Sumber Daya Manusia. UB Press. Malang.

Sugiyono. (2010). Metode penelitian Bisnis. Bandung: Alfabeta.

Syahida, N., \& Suryani, N. (2018). Pengaruh Disiplin Kerja, Lingkungan Kerja Fisik, dan Motivasi Kerja Terhadap Kinerja Perangkat Desa. Economic Education Analysis Journal, 7(2), 610-623.

Usman, H. (2011). Manajemen. Teori, Praktek, dan Riset Pendidikan. Jakarta: Bumi Aksara

Wirawan. (2009). Evaluasi Kinerja Sumber Daya Manusia Teori Aplikasi dan Penelitian. Jakarta: Salemba Empat.

Zhikri, A. (2019). Pengaruh Rekrutmen Terhadap Kinerja Perangkat Pemerintah Desa Sungai Tohor Barat dan Desa Sendanu Darul Ihsan. JDP (Jurnal Dinamika Pemerintahan), 2(2), 115-139. 